\title{
Two not of a kind: Social network theory and informal social networks in East Asia
}

\author{
Sven Horak ${ }^{*}$ \\ St. John's University, New York, USA \\ Markus Taube \\ University of Duisburg-Essen, Duisburg, Germany \& Nankai University, Tianjin, P.R. China \\ Inju Yang \\ EDC Paris Business School, Paris, France \\ Katja Restel \\ University of Duisburg-Essen, Duisburg, Germany
}

\begin{abstract}
In this study, we analyze the core assumptions and ideals of social network characteristics in East Asia and the West. By using an analytical frame derived from the literature and consisting of key antecedents of social networks, we find differences between the conventional assumptions of social network characteristics when comparing them with those found in East Asia. Moreover, we find remarkable intra-regional differences. Among these, and contrary to common beliefs about social networks, we find weak ties are neither truly effective nor preferably used in East Asia, where strong ties are both more preferred and more powerful. Further, social ties tend to be rather consummatory and networks rather closed. Also, depending on the nature of the network, bridging either does not work or is not intended. We recommend further studies explicitly taking local context into account in order to refine or reframe extant knowledge on social networks.
\end{abstract}

\section{Keywords:}

Social capital, social networks, informality, China, Korea, Japan

*Corresponding author (horaks@stjohns.edu) 


\section{Introduction}

While the importance of social capital for economic development, growth, prosperity and social cohesion, among others, has been stressed, it is still unclear whether the term itself or certain dimensions of it can be universally applied or whether it remains a case study that reflects rather a Western context only (Li, 2007a; Qi, 2013; Sato, 2010). Doubt arises as empirical research indicates that East Asia is little endowed with social capital (Lee, Jeong, \& Chae, 2011). On the contrary, although quite collectivistically oriented, countries like Japan, South Korea (hereinafter referred to as Korea) and, recently, China represent excellent role models for rapid economic development. If social capital plays a key role for economic and societal progress, as theory suggests, how could these countries develop so well? Given the collectivistic environment present in all three countries, there is concern that the definitional borders of extant social capital theory may be too narrow or exclude important local context, making its universality claim doubtful.

The question of how social capital is defined has long been a central topic in the literature of sociology and management. Several definitions of social capital exist. According to Bourdieu (1986, 1999), social capital is defined as the total of actual or potential resources which are linked to having access to a network of somehow institutionalized relationships. Further, Burt $(1992,1995,2000)$ focuses more on the aspect of brokerage within the network as a form of social capital and Coleman $(1988,1990)$ and Putnam $(1993,1995)$, who conceptualize social capital at the community level, regard the closure of the network as a source of social capital. It is generally assumed that when institutions are underdeveloped and ineffective, well interconnected network ties serve to facilitate economic transactions. Granovetter's (1985) wellknown embeddedness thesis suggests that actors may not depend too much on institutional arrangement to resolve potential conflicts and opportunism in the market as their embeddedness in a well-connected network provides social norms and obligations that bind people inside of the network. The notion of social capital is therefore linked with the fundamental features of social life - that is, the formation of social networks, social norms and trust, which enable individuals to act more efficiently together realizing common objectives.

Social norms define specific social behavior patterns. Through social networks, the members realize the role and function of social capital, as it usually consists of the means and the result of 
its existence and dynamics. Dyadic social ties between actors are the essential elements of a network. Conventionally, they are described as being rather depersonalized and instrumental rather than consummatory (Portes, 1998) or even sentimental (Bourdieu, 1986). According to Granovetter (1973, 1995, 2017), especially weak ties are of particular value to the individual and important for acquiring information or a job as they introduce novelty from the outside to the network. More recent literature, however, also stresses the role of strong ties in high channelbandwidth constellations for the dissemination of high quality information inside a network (Aral \& Van Alstyne, 2011). In principle, social capital highlights the instrumental dimension of social relations and ties, which can, but do not have to, be based on kinship.

In comparison, informal social networks in East Asia (e.g., guanxi) are described as being a strongly personalized social tie, emotional and less instrumental. It can be kinship-based or non-kinship-based (Li, 2012; Luo, 2000). Also, advantages derived from bridging structural holes, as proposed by Burt (1995, 2000), may not hold in China (Xiao \& Tsui, 2007). These differences spur doubt whether current definitions of informal social networks are rightfully claimed to be universally valid or whether they are valid for Western countries only. Hence, scholars have doubted the unconditional applicability of conventional network theories in East Asia. Sato (2010, 2013), for instance, critically discussed the universal applicability of the concept of social capital and social network in East Asian societies where strong indigenous (i.e., local) concepts of interpersonal relationships exist that are not fully captured by the social capital concept. Further, Li (2007ab) underlines the uniqueness of guanxi as the dominant norm within interpersonal relationships in China. "Guanxi capital" is said to be in principle strong; it can be both instrumental and consummatory, as well as kinship- and non-kinship-based. Hence, divergence from the conventional assumptions about social network characteristics are obvious.

Departing from the assumption that extant social capital and network theories may include too many ideas of typical Western social ties and network characteristics and too few features that are typical for East Asia, in this study, we systematically analyze typical characteristics of social networks in comparison with their counterparts in East Asia. Thus, the purpose of this research is to extend and further develop social capital and social network theories by identifying as yet unconsidered characteristics using local context. We pursue a comparative research approach in order to shed more light on theoretical dissonances aimed at 
enriching and extending extant knowledge. By doing so, our approach follows the "most similar systems design" (MSSD) method proposed by Przeworski and Teune (1970), used to compare similar cases in order to reveal differences. All our three cases-China, Japan and Koreabelong to the same region, narrowly defined as East Asia, and the same cultural sphere of Confucian Asia, as classified by the GLOBE study (House, Hanges, Javidan, Dorfman, \& Gupta, 2004).

This study is structured as follows. First, we present the theoretical access point which is the transaction cost theory (Williamson, 1979, 1996), providing the theoretical base in connection to the most commonly mentioned core assumptions on social network characteristics that we derive from the social capital and network literature and apply further as an analytical frame (e.g., Burt, 1995, 2001; Coleman, 1988; Granovetter, 1973, 1983, 2017). In the next step, we apply the established assessment frame to informal social networks in East Asia, that is, China, Japan and Korea. Furthermore, we report on the results by comparing the three examples from East Asia with the core assumptions on social networks as well as each other. Finally, the results are discussed and implications for theory development, the practice of management and future research are given.

\section{Theoretical foundation}

\section{Informal economic transactions and social networks}

The study is anchored in the increasingly intertwined reasoning articulated in transaction cost theory and economic sociology (Hennart, 2015). Transaction cost theory as originally brought forward by Williamson (1979, 1996; for a critique see Ghoshal and Moran, 1996) and then explicated to economic clubs (i.e., specific type of networks) by Sandler and Tschirhart (1997), provides the general framework for analysis. By focusing on the different framing constellations and risks associated with the multiple types of (potential) economic interaction, it highlights the need for a broad range of governance modes, taking issue with these and their various emanations of asset specificity in particular. Based on the work by Buchanan (1965) on economic clubs, these concepts have for the first time been brought into a systematic context with networks by Sandler and Tschirhart (1997). These point out the specific impact of fixed and variable costs of transacting for the choice of governance modes in such economic communities 
as well as the crucial role of the (limited) number of interacting economic subjects ("club size") for the viability of such arrangements. Economic sociology has contributed significantly to further hone the theoretical grasp of networks as employed by individual economic subjects in order to organize economic transactions by adding new perspectives to the object of research. Granovetter (1973) has sharpened the understanding of social networks by introducing different types (natures) of ties for network organization to the literature. Burt (1995) and Coleman (1988) have contributed with their work on the specific structures of social networks and their respective parameters. An enlightening (non-economist's) view on the economic functionality of social networks has been brought forward with the concept of social capital (Bourdieu, 1986, 1999; Putnam 1995; Burt, 1992; Tsai \& Goshal, 1998). This concept complements the transaction cost perspective by also addressing the "intangible", informal mechanisms supporting economic interaction in social networks by means of e.g. shared norms and values evolving in collectivist societies, reputation developing in multiple (multiplex) relations, high information density in closed networks (and corresponding incentives not to cheat). In this perspective economic interaction is not only facilitated by (consciously designed) transaction cost reducing governance modes, but rather emanates from social structures that facilitate voluntary cooperation and information sharing. As such the value of individual human capital is being multiplied as it is put into a corresponding relationship with other individuum-based human capital and becomes part of a fabric of social capital (Coleman, 1988, 1990; Putnam, 1993). These approaches go along with an exploration of the cohesive power of social networks - what keeps them stable and functional while integrating a substantial number of individuals into a cooperative community. The more economics-based literature has worked out the key functional parameters relating to threshold levels with regard to the (maximum) number of network participants, efficiency and speed of information transmission among network members; the credibility of sanctioning threats against misbehavior; and the relative value of internal network transactions compared to external (e.g., market, firm) activities - for example, measured via the degree of specialization and complexity of the underlying division of labor (Annen, 2003). Authors more rooted in sociological paradigms have added further important parameters pertaining to the social dimension of human interaction. They show, inter alia, that functionally stable social networks feature transparent reputation mechanisms and coalesce toward mutual trust and shared norms 
(Coleman, 1990; Jones et al., 1997; Li, 2003; Li, 2007b, 2008). The creation of such stable social networks appears to be bound to starting conditions where the network members interact in a benign atmosphere featuring a neither too high nor too low network diversity as well as channel band-width of information exchange (Aral \& Van Alstyne, 2011).

Focusing on the motivations, why individual actors should make their own resources available to others in the first place, Portes (1998) has advanced a differentiation between consummatory and instrumental drivers. Making one's own resources accessible to others in the context of social capital pooling networks can be understood as "consummatory" if this behavior is based on the perception of belonging to and the identification with a group of people upholding the same set of norms and values. The provision of individual resources to the network pool then becomes intrinsically motivated, a manifestation of "correct behavior" that is no longer reflected upon. The creation of individually appropriable utility is not explicitly aspired. Individual utility rather arises by default out of the accumulation of pooled social capital and the perpetual strengthening of shared norms and values which may facilitate additional utility generating interaction. The second driver motivating individuals to allow others to make use of their resources in Portes' classification is a straightforward cost-benefit calculation. Individual resources are contributed to a common pool of social capital, because direct benefits are expected to arise from this move. Shared norms and values of network members are neither a motivating force nor required as such. This latter aspect, however, raises the need for specific arrangements that establish sufficient trust in the value of such transactions.

A defining characteristic of social networks is the lack of a supra-positioned judge for any conflicts arising in network exchanges. Instead, any conflicts must be solved in the realm of bilateral exchange. The standard transaction cost approach is to create a governance mechanism that discourages opportunistic behavior by making a breach of network disciplines more costly (in materialistic terms) than their observance. One solution, for example, might be the exchange of hostages or collateral (Williamson, 1993). Extending this cost-utility concept beyond the sphere of economic goods, the concept of multiplexity provides a further approach for upholding network discipline. Given the non-exclusively economically defined existence of man and the embeddedness in social relations with family, friends, neighbors and others, punishment for misbehavior in the economic sphere can be sanctioned in another (social) sphere, for instance, if 
punishment in the economic sphere is impossible or insufficient (Ben-Porath, 1980). Moving even further beyond the cost-utility paradigm, the creation of value communities and the evolution of mindsets, in which the adherence to network norms becomes a source of satisfaction (an intangible value) in itself, constitute a further means of promoting cooperative behavior (Li, 2003; Li, 2008). Such a socialization of network norms can evolve only over longer periods of time in close-knit communities and cannot support network communities in their early stages of development. Once established, however, it can also promote the consummatory injection of individual resources and the accumulation of social capital in the network as outlined above.

A powerful tool for comparative research on the idiosyncrasies of social networks as they have developed in different cultural environments and functional requirements (Adler, Doktor, \& Redding, 1986; Dowling \& Donnelly, 2013) is provided by the analytical concepts of "structural embeddedness" and "relational embeddedness" (Aoki, 2007; Hennart, 2015). "Structural embeddedness" pertains to the capacity of social networks to discourage opportunistic behavior and uphold disciplined, norm-abiding behavior by all network members. It captures the strength of a network in the sense of structural stability, which is understood to be most pronounced in closed networks in which all members stand in direct relation to all other members. In such an environment, information about breaches of network discipline travels fast, facilitates immediate sanctioning and, most importantly, allows for the fast establishment of positive or negative reputation. Consensus about shared norms and values is quickly established and then perpetually strengthened in iterative transaction patterns among well-informed network members (Aoki, 2007; Burt, 2000).

"Relational embeddedness" is looking at a second structural dimension of social networks by focusing on the nature of the multitude of dyadic ties constituting a specific network, thereby taking up Granovetter's $(1973,2017)$ concept of strong and weak ties. To be more precise, the concept of "relational embeddedness" actually focuses on the relative frequency of strong and weak ties in a specific network and the implications of these for the functionality, value-creating capacity and stability of networks. The analytical cornerstone of this approach is the notion that strong ties-that is, frequent dyadic interaction-nurtures the evolution of shared norms and trust, facilitates the establishment of reputation and allows for effective sanctioning of misbehavior. As such, networks predominantly based on strong dyadic 
ties should be understood as highly stable and functional. In terms of their ability to create value for network members, however, weak ties might be more instrumental. Weak ties are understood to constitute less frequent interaction among partners that uphold intermittent exchange relations with a multitude of partners. Such ties are certainly less instrumental for the creation of shared norms and trust in a dyadic relationship, but exactly by reaching out of rigid network routines they can introduce new information, tap into new resources and bridge structural holes (Burt, 1995, 2000). Weak ties are better positioned to create new value in a given network and propel its members to higher utility levels.

As such, the relative prevalence of strong and weak ties, and by the same logic the high or low degree of structural embeddedness, indicates a tradeoff between the ability to quickly establish and uphold stable network structures on the one hand and the capacity to dynamically develop new spheres of interaction and utility for network members on the other. Similarly, these different types of networks react differently to exogenous shocks. Structurally highly stable networks dominated by strong ties feature a pronounced inertia toward shocks and will be able to perpetuate their functionality even in highly adverse environments. At the same time, however, they have little capability for adaptive change toward new exogenous challenges and stand in danger of losing their functionality over time. Networks with lower structural stability but a high share of weak ties face a higher danger of quick disintegration in the face of exogenous shocks, but also have a higher capability of adapting to changing environments, integrating new impulses and reinventing themselves. If they have sufficient time to adapt, such networks are less prone to becoming extinct but instead evolve toward new forms adapted to new worlds (Hennart, 2015).

\section{Characteristics of social networks}

Inspired by a scheme as applied, for instance, by Li (2007a) or Horak and Taube (2016), we discuss six critical core assumptions of informal social networks in the following and utilize these antecedents as the basis for comparison in later sections.

Emotional involvement. Social ties in business and management studies are typically distinguished according to the emotional involvement of actors. Influential work for the management discipline proposed personal ties in business to be more rational and free of emotional involvement (Blunt \& Merrick, 1997). The Weberian approach to management had a 
lasting influence on the practice of (Western) management, represented by a powerful and authoritative leader and work organization relying on rather bureaucratic, formal and depersonalized processes (Blau \& Meyer, 1971; Weber, 1922). Because in the West a management ideal has been objective decision-making - free from emotional bias, cronyism and any related doubtful practices - the idea that weak ties are a better choice for instrumental action comes as no surprise (Granovetter, 1973, 1983; Lin, 1999). Used instrumentally, weak ties lead to positive outcomes for job acquisition (e.g., Granovetter, 1973) and individual career success (Ibarra, 1995; Seibert, Kraimer, \& Liden, 2001). Typically, in the West a business relationship is rather cognitively based upon the perception of the counterparts' competence, ability and integrity (McAllister, 1995; Jeffries \& Reed, 2000; Parayitam \& Dooley, 2009). Hence, the establishment of a sentimental relationship usually starts after a deal is concluded rather than before (Ambler, 1994; Lovett, Simmons, \& Kali, 1999; Park \& Luo, 2001). In sum, social network theory tends to regard social ties in social networks as rather instrumental in nature without a need for a consummatory basis or even a friendship-like emotional involvement (see also Adler \& Kwon, 2002; Burt, 2001; Portes, 1998).

Relative tie strength. Granovetter (1973) distinguishes between strong and weak ties and tends to ascribe higher importance to the latter in interpersonal transactions. By nature, strong ties are informal and considered emotional and intimate; trust is said to be pronounced. On the contrary, weak ties are largely non-affective, utilitarian and infrequent as actors are usually not closely related; these ties are rather loose (Nelson, 1988). Strong ties are assumed to be unable to connect different network communities since by nature they cannot establish bridges between networks, as "all bridges are weak ties" (Granovetter, 1973: 1364). It is assumed that particularly weak ties exert long-range influence by e.g. enabling information to travel to distant parts of the network. In order to characterize the nature of typical group-based social ties in the West that form social capital on an aggregate level, Li (2012) suggested that they are generally weak, depersonalized and usually non-kinship-based. In sum, it follows that while most authors consider diverse ratios of strong and weak ties as ideal, weak ties are usually understood to contribute most to the advancement and "wealth" of a specific network as well as to strengthen its capability to adapt to exogenous shocks and changing environments. At the core to this proposition lies the assumption that weak ties are especially suited to introduce new ideas to a 
network from the outside. However, while the 'strength of weak ties' argument (Granovetter 1973 , 1983) has been very influential, it has to be noted that some scholars put forward important counter-arguments supporting a 'strength of strong ties' thesis for China (Bian, 1997) as well as for a Western environment. Studies on conflict in organizations, for instance, show that weak ties alone are not sufficient to reduce conflicts. It is rather the strong ties that are dominant in lowconflict organizations. They support cooperation and hence increase organizational effectiveness (Nelson, 1989; Krackhardt \& Stern, 1988). Krackhardt (1992) underlines the importance of friendships (or 'philos' in Greek) as an important and strong-tie-based resource in major organizational change processes that require confidence of whether they will be successful before they occur. These predictions can be made best by relying of friendships or strong ties. A further example is the study of Rost (2011) on the creation of innovation. In this study it is argued that the influence of weak network ties is generally overestimated in innovation research. Rather weak and strong ties are connected in a sense that weak network ties leverage the strength of strong ties in creating innovation. Aral \& Van Alstyne (2011) go on step further by arguing that weak ties are restricted in terms of frequency and band-width resulting in low quality information being transferred at a slow rate. As a result they argue that over time stronger ties might provide greater total novelty to network members than weak ties.

Openness. By the openness of networks, we mean whether individuals can get access to them or are per se excluded. In other words, are social networks rather open or closed by nature? In fact, they can be characterized as being both (e.g., Son \& Lin, 2008), depending on the strengths of ties. Networks consisting of strong ties tend to be more closed, while those with weak ties are more open. However, research tends to postulate the "utility of open networks and weaker relations, because such extensive relations afford reaching others with richer and more diverse resources" (Son \& Lin, 2008: 334). Especially the assumption that weak ties are most valuable leads to the picture that everyone who has additional resources to contribute to a network - thus increasing the social capital endowment of the whole-would or should be granted access to some extent (Burt, 2001; Granovetter, 1983). Further, striving for the maintenance of diverse ties, in order to increase the overall values of an actor's social capital endowment (Burt, 1997), implies that though networks can be more or less open or closed, they are in principle receptive to new entrants. From a Western point of view, it can be regarded a 
core assumption that social capital tends to be accessible, once actors possess social skills that enable them to access and develop social capital (Baron \& Markman, 2000; Glaeser et al., 2002; Sander \& Lowney, 2006).

Bridging. A further core assumption in social network theory is that unconnected networks can be bridged or connected through a broker (the "tertius gaudens", i.e., the third who benefits). It is observed that so-called structural holes (Burt, 1995) can be filled with a node in the form of a broker. The broker has an informational advantage by drawing on different sources and by sharing this advantage with other network members, who in turn benefit by a larger amount of information available. Due to the benefits that social ties to several networks bring, it is recommended that organizations establish a mix of ties, both weak and strong, to several actors. However, it is finally assumed that the weak ties appear to be more influential and beneficial (Burt, 1997, 2000). Hence, a core assumption is that unconnected communities in a network sense can be connected in principle through a broker.

Kinship base. According to classic social science theory, kinship and pseudo-family ties are said to diminish along with increased democratization and economic development as well as the reliance on formal institutions and more open networks (Durkheim, 1933). That means it is assumed that relationships in developed economies are largely based on formal contracts and weak ties among actors. Family or quasi-family ties (i.e., strong ties) are expected to successively diminish and will not play a strong role in the long run. Social network theory contains much of that idea and influences the assumptions about whether people use a greater number of strong or weak ties. Further, by drawing on Pool (1980), Granovetter suggests that people using predominately strong ties "may be socially isolated and forced to fall back on weak ones" (Granovetter, 1983: 210). Again, relying only on strong ties has a rather negative connotation and is assumed not to work out successfully for the benefit of the actor. Finally, $\mathrm{Li}$ summarizes the core assumption in social network theory that regards ties typically as "largely depersonalized and primarily non-kinship-based" (Li, 2012: 853).

Purposiveness. Based on the above, it becomes obvious that social networks, especially as described in the business and management literature, are predominately used to acquire material or non-material benefits or resources. While acknowledging different types (Claridge, 2004), it can be claimed that social capital is usually seen as instrumental in achieving a purpose 
in some form. Several definitions underline the purposiveness and put forward, for instance, its facilitative function needed for "coordination and cooperation for mutual benefit" (Putnam, 1995: 67). Social capital is said to consist of "friends, colleagues, and more general contacts through whom you receive opportunities to use your financial and human capital" (Burt, 1992: 9) or is characterized by pointing out "the brokerage opportunities in a network" (Burt, 1997: 355), just to name a view prominent definitions. In sum, it can be said that, conventionally, social networks serve a material or non-material purpose. Table 1 summarizes what has been discussed. Having clarified the core assumptions of social networks, we analyze below informal social networks in China, Korea and Japan by using the framework devised.

Table 1: Informal social networks - Selected antecedents and typical characteristics

\begin{tabular}{|c|c|c|}
\hline Dimension & Dichotomy & Core assumption \\
\hline Emotional involvement & $\begin{array}{l}\text { Instrumental - } \\
\text { consummatory }\end{array}$ & $\begin{array}{l}\text { Dominant ideal: instrumental/ } \\
\text { utilitarian }\end{array}$ \\
\hline Relative tie strength & Strong - weak & Weak ties characterize social networks \\
\hline Openness & Open - closed & $\begin{array}{l}\text { Generally accessible, receptive for } \\
\text { new entrants }\end{array}$ \\
\hline Bridging & Connected - disconnected & $\begin{array}{l}\text { Bridging between separate networks } \\
\text { works and is beneficial }\end{array}$ \\
\hline Kinship base & $\begin{array}{l}\text { Kinship-based - non- } \\
\text { kinship-based }\end{array}$ & Predominantly non-kinship-based \\
\hline Purposiveness (gain) & $\begin{array}{l}\text { undesigned - (non-) } \\
\text { material }\end{array}$ & $\begin{array}{l}\text { Social networks are predominantly } \\
\text { used to acquire gains }\end{array}$ \\
\hline
\end{tabular}

\section{Characteristics of informal social networks in East Asia}

\section{The case of China: Guanxi}

Social networks in China are first and foremost associated with the notion of guanxi. Other concepts like yuan (缘) or yuanfen (缘分), expressing the perception of a shared destiny or fateful bond, and renmai (人脉), which indicates ego-centered networks based on personal trust, have been either marginalized (yuan, yuanfen) or have become integrated in the larger guanxi discourse (renmai) (Luo, 2006). Guanxi (关系, in simplified characters) means first and foremost relation or relationships; however, this definition is almost too loose to grasp the real meaning of this uniquely Chinese phenomena (Li, 2007a). Guan (关) basically means “a pass or barrier” as a 
noun and "to close" as a verb, whereas the second part of the word, $x i$ (系), means "a system" or, if read as a verb, "to tie up" or "to link" (Bian, 1994). ${ }^{1}$ The term embodies the Confucian norm of reciprocity and is focused on family and kinship (Chen et al., 2013; Li, 2007a, 2007b; Luo, 2011). Simplified, guanxi depicts the relationship between people, objects and forces (Yang, 1994), and relies on formed mutual obligation and reciprocity with a rather flexible time frame for repayment of certain favors (Gold, Wank \& Guthrie, 2002). It can also be defined as a sort of friendship implicating a continued exchange of favors (Pye, 1982). Due to a lack of obligation toward other impersonal groups such as political institutions (Weber, 1951), guanxi has served to provide certain goods and welfare (Fan, 2002a, 2002b) and has been employed as a substitute for an established rule of law (Xin \& Pearce, 1996; Taube \& Schramm, 2003). Guanxi is a "typical social tie in the East, is a dyadic social tie, both sentimental and instrumental, strongly personalized, kinship- or non-kinship-based" (Li, 2012: 853). Nowadays however, guanxi is also used to generate trust for illegal exchanges and stands in contrast to newly established rules and regulations about to become stronger (Ledeneva, 2008).

The emotional involvement in guanxi relations and/or networks can be either instrumental or consummatory (sentimental), depending on their origin and intent ( $\mathrm{Li}, 2012$, see also Bian, 1997). It can be seen as friendship with a mainly social component (Pye, 1982) but also as a platform for the exchange of certain goods and favors, yet with an emotional component (Barbalet, 2015). China's transition from being a communist society with Confucian heritage to becoming more capitalist opened up further venues for more opportunities where solely instrumental connections are necessary (Ledeneva, 2003, 2008; Taube \& Schramm, 2003; Zhan 2012). Nowadays strong and weak guanxi ties coexist in Chinese society. The strength of guanxi ties also depends on the specific origin of the network and/or relationship and its intent. Guanxi evolved from clan-based structures and was determined by strong ties shaped by family and geographic origin during the Qing dynasty, though it gradually changed (Barbalet, 2015). With the economic reforms in the 1980s came more geographical mobility and also weaker guanxi ties (Chang, 2011). Guanxi networks can be either closed or open, depending on their origin and nature. Whereas village- or family-based networks are rather difficult if not impossible to get into (Lin, 1995), networks formed at the workplace or for a specific purpose, on the other hand, are easier to get access to. Due to the different levels of tie strength as well as 
the diverse levels of network openness, bridging is possible to a certain extent. Every Chinese person belongs to at least one guanxi network, and usually to more since certain characteristics (heritage, job, family) can allow access to different networks that sometimes overlap (one can be born to family $\mathrm{X}$ and also in village $\mathrm{Z}$ with school affiliation $\mathrm{Y}$ and a job in $\mathrm{Q})$. There is no such thing as open rivalry between the networks. Even though guanxi's origins are traditionally kinand family-based, those terms are more flexible than in the Western sense. Family ranges from the nuclear family to very extended familial relations such as distant cousins who are also embraced as family members. Family association can be inherited by birth or by marriage (Tsui $\&$ Farh, 1997). With the emergence of a more capitalist society and a slow erosion of traditional bonds, guanxi networks can also be composed of people who went to the same school or university, work at the same company or simply have shared goals to achieve. In general, it can be stated that guanxi networks first and foremost serve the purpose of generating trust between their members by executing social control in a setting where rule of law and formal institutions such as courts are non-existent or underdeveloped. They also provide a sense of belonging in a collectivistic society (Tsui \& Farh, 1997). However, historically-and even up until the time of Mao-guanxi networks served as a means of facilitating trust but also of combating material shortages and allocating and redistributing state-owned goods, thus supporting the status quo (Ledeneva 2003, 2008). With the economic reforms and the rise of a more capitalist worldview, guanxi relations have become more purpose-based, inter alia paving the way to corrupt exchanges (Leung, 2008; Taube \& Schramm, 2003; Taube, 2013). Table 2 summarizes what has been discussed.

Table 2: Guanxi - Selected antecedents and typical characteristics

\begin{tabular}{ll}
\hline Antecedent & Characteristic \\
\hline Emotional involvement & Consummatory and instrumental \\
Relative tie strength & Strong ties and weak ties \\
Openness & Varying degrees of openness \\
Bridging & Bridging between separate networks is possible \\
Kinship base & Traditionally kinship-based, but open to non-family \\
& members today \\
Purposiveness & Exists in the first place to serve a relationship and to \\
& facilitate trust. Also, to provide a platform for exchange \\
& of certain goods and favors \\
\hline
\end{tabular}




\section{The case of Korea: Yongo}

Three forms of common networks are distinguished in the literature: Inmaek (인맥), yonjul (연줄) and yongo (연고). Inmaek can be directly translated into the English term "network" and as such it does not imply or indicate a special characteristic. It describes relationships that an individual develops in the course of life. Yonjul denotes ties used to achieve a goal. The word has a negative connotation and is widely seen as unethical as it is often connected to dubious transactions (Horak, 2016). Whereas the word guan-gye (or kwan'gye) is used to refer to relationships, Yongo is usually considered the most typical Korean network form that characterizes Korean society (Horak, 2014; Lew, 2013; Renshaw, 2011; Yee, 2000). Yongo embodies the trustful and emotional ties existing in Korea, a society deeply embedded with a Confucian value system (Kim \& Bae, 2004; Kim, 2000). The term yongo represents informal ties in Korea, where the syllable yon stands for "tie," signifying an bond between individuals based on shared norms and or experiences. This consummatory connection or bond, represented by the syllable $g o$ is based on a shared background. This shared background is due to a shared geographical origin (jiyon, 지연), affiliation with the same family (i.e., being connected by blood ties; hyulyon, 혈연), or having attended the same high school and/or university in Korea (hakyon, 학연) (Horak \& Yang, 2016). Yongo is defined as "the term for personal relationships in Korea that are attached to affiliation to an informally organized group. [...] Yongo derives its main cohesion power from strong particularistic ties, based on kin, educational institution (school/university) and region" (Horak, 2014: 87). Yongo networks already existed during the Choson dynasty (ca. 1392-1910), when the ruling Yangban class "grouped itself into mutually exclusive factions and clans that engaged in fierce rivalry. The fragmentation of the Yangban society along the line of scholarly association, kinship and region gave rise to purges and factional strife." (Sik, 2005: 84). A very distinctive characteristic of yongo ties is the circumstance that they are mostly acquired by birth, with the exception of the hakyon ties since the university association can be chosen freely (Horak, 2014). Hence, yongo is immutable and irreversible. All these bonds last for life and are maintained by informal meetings of the respective network members (Horak, 2014). However, it has to be pointed out that defining a 
multidimensional and dynamic construct like yongo can be tricky. It can be assumed that, for instance, not all jiyon-based ties are per se and equally strong. Rather, as jiyon is ascribed it can be developed towards a stronger tie, depending on how much effort the parties put into them or how important and influential individuals are perceived. As for hakyon-based ties, that are certainly not ascribed, as explained above, it should be noted that they may be strategically nurtured and build over time. Parents may select universities for their children with high yongoendowment, so that they benefit by growing early into an existing network to potentially become part of the future 'upper echelon' network of the Korean society. Thus, yongo can be alternatively seen as very long term strategic investment into becoming a part of existing networks, although initially individuals may not be fully aware of this at young age. However, as management research has so far explored yongo to a lesser extent, future research may verify the assumptions made above.

In principle, yongo is not formed due to an instrumental interest per se, as it derives from one's ascription to these ties (jiyon, hyulyon and hakyon, the last in an ex-post sense). Lew (2013) proposes the rather generic term "affective network" for yongo, which clearly implies that affection is a fundamental social cohesion element of yongo. Hence, it can be regarded as a consummatory type of social tie.

Since yongo affiliation cannot be freely chosen, in principle (with the exception of hakyon nowadays), there is a sense of quasi-family belongingness among its members, supported by the strong Confucian heritage of the Korean environment (Kim \& Bae, 2004; Kim, 2000). Hence, norms of behavior are pronounced and informally enforced by peer pressure. Often yongo-based ties are maintained and last for life. Compared to the strength of typical network ties in the West, yongo-based ties can be regarded as strong ties in principle. However, it has to be mentioned that there is a research gap leaving important questions in relation to yongo unanswered. These are, among others: Can yongo ties in retrospect acquired through marriage (hyulyon, or blood ties) be regarded strong per se? Do they lead to access to the network and can they penetrate the network deeply? Can jiyon be acquired through living in a certain place for a long time without being born there? If so, are these ties as strong as congenital jiyon? In order to measure and quantify yongo more precisely, a dedicated indigenously-oriented research agenda is urgently needed. 
As mentioned above, one of the distinctive features of yongo is its predefined nature, with hakyon ties being the only exception, since university affiliation can be chosen more or less freely. Yongo networks are rather closed to outsiders and membership based on qualities such as merit is almost impossible to acquire.

Bridging networks within a different line of ties (for example hakyon, between university A and university B) is difficult since there can be fierce rivalry between both networks. On the contrary, bridging networks within the same line of ties works very well as this is considered an "intra-family" affair. According to Kim (2000), within the same line of ties there is "flexibility, tolerance, mutual understanding as well as trust. Outside the boundary, on the contrary, people are treated as 'nonpersons' and there can be discrimination and even hostility" (Kim, 2000: 179).

In essence, yongo is primarily (quasi-) kinship-based with the spirit of familial ideals of belongingness and mutual obligation shaping the culture of social ties and networks as they are embedded in a Confucian value frame.

As yongo is cause-based (rather than acquired through merit and achievement) and not purpose-based (since it traditionally consists of the aforementioned three mostly pre-existing ties), it is immutable and irreversible (Horak, 2014). It can be regard as the typical concept that shapes the Korean society and thereby defines social relationships. As scholars used to call Korea a network society (e.g., Lew, 2013; Kim, 2000), yongo (as well as inmaek) would be the terms to define what network society actually means in a local context. Thus, as a societal form, it does not in principle imply a purpose per se. However, it can serve as a platform for achieving a purpose, if needed. We summarize the key findings of this section in Table 3.

Table 3: Yongo - Selected antecedents and typical characteristics

\begin{tabular}{ll}
\hline Antecedent & Characteristic \\
\hline Emotional involvement & Consummatory \\
Relative tie strength & Comparably strong to very strong \\
Openness & Closed \\
Bridging & $\begin{array}{l}\text { Bridging only between networks that are not in the same } \\
\text { tie-line }\end{array}$ \\
Kinship base & $\begin{array}{l}\text { Network is historically kinship-based, but other forms } \\
\text { are also possible }\end{array}$ \\
Purposiveness & Cause-based \\
\hline
\end{tabular}




\section{The case of Japan: Kankei, jinmyaku, en, aidagara}

Different from both Chinese guanxi, which becomes the representative expression in describing relationships in the Chinese context, and the rather closed and ascribed yongo in Korea, there are various words to support the importance of relationships in Japan, including kankei (かんけい: 関係) and jinmyaku (じんみゃく: 人 脈) as well as en (えん: 縁) and aidagara (あいだがら： 間 柄). First of all, kankei has the same Chinese characters as guanxi, which means relationship. Kankei is often used with another word, ningen (人 間) which indicates people or, more precisely, people (人) in-between (間). Ningen kankei involves closeness and cooperation between people in mutually beneficial relationships. Shared experiences create special bonds between people that are part of ningen kankei (Cheung, Wu, \& Wong, 2013). Ningen kankei could include people from the same town, former classmates or coworkers. Similarly, jinmyaku is another Japanese word illustrating the social networks of people. Developing social and professional networks of contacts is a very important custom in Japan and the length of a relationship almost always correlates with the depth and importance of the relationship (Sharp, 2013). While the direct translation of en is connection, it describes a momentum, or "fate", that makes two persons encounter. If a person happens to get acquainted with another person, for example, he or she would say, "We got to know each other due to some en, so why don't we keep a good relationship?" (Sato, 2010: 193). With en, people are essentially connected to one another. In a similar vein, aidagara or being between indicates social relations or contexts. It signifies subsystemic connections between people that are formed within the extremely large system of human causal chains - the system of en. Relationships within aidagara are based on mutual favors since the parties involved are not considered mutually separate entities (Hamaguchi, Kumon, \& Creighton, 1985). People have always been seen in their "in betweenness" in relationships with others as ningen (people) because the jibun (自分) or the self has a relational and relative character shared by both oneself and other actors (Hamaguchi et al., 1985). The communal takes priority over the individual or jibun (Watsuji, 2007), and the social system demands self-restraint as the self is dependent upon other actors (Hamaguchi et al., 1985).

These Japanese concepts of kankei, jinmyaku, en and aidagara are quite similar to each other, although there are subtle differences in their focus, namely experience-based relations, 
intensity of networks, a fate-like connection and interdependent betweenness, respectively. We adapt these Japanese notions interchangeably in discussing their characteristics in detail below.

Japanese social ties are to a great extent emotionally driven rather than instrumentally motivated. The affective nature of social networks can be easily observed from the kankei relationship, for example. Japanese kankei supervisors are expected to help their subordinates learn the requirements of a particular job as well as to look out for the interests of their subordinates and take responsibility for their subordinates' errors (Cheung et al., 2013; Clark, 1979; Cole, 1971). Whereas Japanese kankei subordinates expect protection from their supervisors if something goes wrong (Chen, 1995; Clark, 1979), the subordinates are obligated to return the favor by working hard and displaying loyalty. Likewise, Japanese kankei blurs the distinction between cognitive work and affective private lives (Cheung et al., 2013). A kankei relationship tends to be more natural as it involves a concern for human feelings and dependence (Clark, 1979), and after-hours social gatherings are important for the development of kankei (Cheung et al., 2013). Consummatory factors weigh strongly in Japan (Fukuda, 1993; Yazawa, 2006), and exchange relations do not necessarily take the form of simultaneous, equal transactions. The know-how for getting along well in life involves the ability to assume an attitude of self-deprecation to treat one's partner with due respect (Hamaguchi et al., 1985). Norms and unwritten law (Hirt \& Schneider, 2003) also characterize kankei relationships as moral and contractual obligations which favor the weaker party (e.g., subordinates) in gaining access to the support from the stronger party (e.g., supervisor) (Cheung et al., 2013).

Interpersonal links in Japan can be described as having strong ties. Once a kankei relationship is established, members regard each other as lifelong members and will protect each other's welfare by all means. It is also argued that kankei has a longer orientation than guanxi (Cheung et al., 2013).

Social networks in Japan are considered to be closed, working via long-standing relations of mutual trust (Kumon, 1992). Japanese expect relationships to grow and develop by playing the long game and to be continuously rewarding. They put in the time and effort to demonstrate their loyalty in line with the urge to develop deeper long-term relationships or jinmyaku. Jinmyaku is about trust shared between members (Sharp, 2013). In a similar vein, the use of kankei is to deny access to outsiders and to grant access to the close kankei for retrieving valuable information 
(Cheung et al., 2013). Accordingly, social networks in Japan are criticized for not being flexible, causing them to become alienated and bureaucratized (Yazawa, 2006). Bridging between separate networks does not work in principle, nor is it intended to. In line with the Asian qualities of emphases on the family, respect for elderly and face-saving (Giridharadas, 2011; Shirahase, 2014), mutual monitoring among kin and coworkers makes for a Japanese society based on strong ties (Chua \& Wellman, 2015). In accordance with Japanese promotion of group and community orientation, kankei subordinates are willing to stay loyal to their organizations and obey the work orders of supervisors (Cheung et al., 2013). Those who experience $b a$ (場), or a shared context in which participants create new meanings through interactions (Nonaka \& Toyama, 2002), would mutually construct a collective self (Yazawa, 2006). In a similar vein, kankei is largely formed on the basis of social factors rather than on similarities in visible and common backgrounds (Xie, 2012). Network structures such as kin-centeredness, hierarchy and work orientation illustrate how personal connections are embedded in several Asian societies, including Japan (Chua \& Wellman, 2015).

Stable human relations provide communities and their inhabitants with security and assurance (Sato, 2010). Social ties in Japan do not regard an equal exchange as a primary concern since human relations are not mere temporary reciprocal interactions (Hamaguchi et al., 1985). Hence, serving the relationship can be regarded the prior purpose of the tie. Networks of relational contracting in Japan are characterized by risk-sharing, long-term advantage and goodwill. It is that sense of duty over and above the terms of a written contract which gives the assurance of the payoff (Dore, 1983). Here, on (恩) and giri (義 理) may be regarded as moral sanctions that are directly related to such forms of exchange (Hamaguchi et al., 1985). On means unilateral and voluntary services given to one by members of society, and giri means duty or obligation. With aidagara relations, preference is given to mutual favors between persons who are connected, and effort is expended to maintain the relationship itself, thus transcending individual interests (Hamaguchi, 1985). The relationship itself is considered to be intrinsically invaluable, and it is more important to give consideration to others to the point of ignoring one's own gains (Hamaguchi et al., 1985). Table 4 provides an overview of the discussed antecedents and characteristics. 
Table 4: Japan - Selected antecedents and typical characteristics

\begin{tabular}{ll}
\hline Antecedent & Characteristic \\
\hline Emotional involvement & Consummatory \\
Relative tie strength & Strong ties \\
Openness & Low degree of openness \\
Bridging & Bridging between separate networks is not intended \\
Kinship base & Strong quasi-familistic ties prevail \\
Purposiveness & Serving a relationship is the prior purpose \\
\hline
\end{tabular}

\section{Results}

Comparing the three East Asian social networks to the typical characteristics conventionally ascribed to social networks reveals remarkable differences. Also, an intra-regional comparison shows that there is a noteworthy heterogeneity among the East Asian networks (see Table 5). In what follows, we point out differences in characteristics between the three East Asian networks and the core assumption about social networks in general, followed by an intra-regional comparison.

Social networks, especially in the management literature, are implicitly and explicitly characterized as being predominantly instrumental or utilitarian in nature. In East Asia, on the contrary, the emotional involvement of actors is far more pronounced; it is rather the norm than the exception. East Asian networks can be, by trend, predominantly described as consummatory by nature, especially those in Korea and Japan. However, research on guanxi in China finds both characteristics: instrumental and consummatory. While the social network literature acknowledges strong and weak ties, the weak ties in particular are not only important to the individual to, for example, progress professionally, they are also seen as the source for a civil society to further develop and flourish. Whereas guanxi ties can be strong or weak, social ties in Korea and Japan, two of the most industrialized countries, can be characterized as rather strong. The literature indicates that weak ties are seldom used because people in Korea (e.g., Yee, 2000) as well as in Japan (e.g., Watanabe, 1987) would rather rely on strong ties. Instead, the ideal is to have or develop strong ties since weak ties are not deemed useful. Further, the social network literature indicates that networks are receptive in principle, that is, to varying degrees they are open to new entrants. Whereas this corresponds to what is known about guanxi ties, Korean yongo ties are rather closed and certain ties in Japan also show a rather low level of openness. 
Hence, bridging of networks by a broker may work well in China in principle (see also Xiao \& Tsui, 2007), but it goes against the logic of yongo-based ties in Korea, where bridging of the same tie line is nearly impossible as communities of the same tie line (e.g., hakyon, hyulyon or jiyon) may feel discomfort toward each other or even hostility (Kim, 2000). Similarly, in Japan, bridging between separate networks is not intended. Whereas social network theory tends to focus on typical (weak) social ties to be conducted voluntarily among a group actors, in contrast to family, quasi-family or clan or kinship ties, we see in all three East Asian network forms a strong connotation of pronounced family or quasi-family ties. Especially in China, strong kin and non-kin guanxi ties are pervasive ( $\mathrm{Li}, 2007 \mathrm{~b})$. The simple question of what purpose social networks serve would likely be answered in the West with arguments such as gathering information, acquiring a job or becoming part of a circle that makes oneself more relevant and poised for the next promotion. In any case, social networks fulfill in the first place a purpose. Although at times they overlap, there is a distinction between social networks and friendships. In contrast, in East Asia, social networks primarily serve a relationship and establish trust. In Korea, it can be said that yongo ties are preset (except university-based ties), and hence exist already without a purpose per se, though they can be used for a purpose.

Comparing networks in East Asia with each other reveals certain similarities but also large differences. Most similarities occur in terms of emotional involvement, relative tie strength, openness and bridging of ties that are relatively similar in Japan and Korea; however, both are more pronounced than in the case of China. In China, guanxi ties can be instrumental and weak, whereas in Japan and Korea ties are predominately strong and consummatory. Likely because of these characteristics, ties in Japan and Korea tend to be more closed, whereas becoming a member and establishing guanxi in China can be easier.

In sum, we see in part fundamental differences between the core assumptions of social network theory when compared to key characteristics of social networks in East Asia, but there is also heterogeneity among the latter. Although they share the same regional origin (i.e., East Asia), the characteristics of the three are partly similar but not exactly the same. Surprisingly, we see most similarities between the networks in Korea and Japan (see Table 5), contrary to the expectation that mainland social networks (e.g., China and Korea) would show more similarities compared to island countries (e.g., Japan). This observation might not be that surprising if one 
follows the proposition that Korean and Japanese social networks should be more similar to each other than vis-á-vis Chinese networks as the former are on a higher level of economic development and further apart from traditional family-based economic structures. This proposition certainly needs further research. But inter-temporal observations of the nature of social networks in these three societies show little changes, despite of dramatic changes in economic structures and welfare levels.

Table 5: Overview - Core assumptions and key characteristics of social networks in East Asia

\begin{tabular}{|c|c|c|c|c|}
\hline Dimension & $\begin{array}{l}\text { Core } \\
\text { assumptions }\end{array}$ & $\begin{array}{l}\text { China } \\
\text { (guanxi) }\end{array}$ & $\begin{array}{l}\text { Korea } \\
\text { (yongo) }\end{array}$ & $\begin{array}{l}\text { Japan } \\
\text { (various) }\end{array}$ \\
\hline $\begin{array}{l}\text { Emotional } \\
\text { involvement }\end{array}$ & $\begin{array}{l}\text { Dominant ideal: } \\
\text { instrumental/ } \\
\text { utilitarian }\end{array}$ & $\begin{array}{l}\text { Consummatory and } \\
\text { instrumental }\end{array}$ & Consummatory & Consummatory \\
\hline Relative tie strength & $\begin{array}{l}\text { Weak ties } \\
\text { characterize social } \\
\text { networks }\end{array}$ & $\begin{array}{l}\text { Strong ties and weak } \\
\text { ties }\end{array}$ & $\begin{array}{l}\text { Comparably strong } \\
\text { to very strong }\end{array}$ & Strong ties \\
\hline Openness & $\begin{array}{l}\text { Generally } \\
\text { accessible, receptive } \\
\text { to new entrants }\end{array}$ & $\begin{array}{l}\text { Varying degrees of } \\
\text { openness }\end{array}$ & Closed & $\begin{array}{l}\text { Low degree of } \\
\text { openness }\end{array}$ \\
\hline Bridging & $\begin{array}{l}\text { Bridging between } \\
\text { separate networks } \\
\text { works and is } \\
\text { beneficial }\end{array}$ & $\begin{array}{l}\text { Bridging between } \\
\text { separate networks is } \\
\text { possible }\end{array}$ & $\begin{array}{l}\text { Bridging only } \\
\text { between networks } \\
\text { that are not in the } \\
\text { same tie-line }\end{array}$ & $\begin{array}{l}\text { Bridging between } \\
\text { separate networks is } \\
\text { not intended }\end{array}$ \\
\hline Kinship base & $\begin{array}{l}\text { Predominantly non- } \\
\text { kinship-based }\end{array}$ & $\begin{array}{l}\text { Traditionally } \\
\text { kinship-based, but } \\
\text { open to non-family } \\
\text { members today }\end{array}$ & $\begin{array}{l}\text { Network is } \\
\text { historically kinship- } \\
\text { based, but other } \\
\text { forms are also } \\
\text { possible }\end{array}$ & $\begin{array}{l}\text { Strong quasi- } \\
\text { familistic ties prevail }\end{array}$ \\
\hline Purposiveness & $\begin{array}{l}\text { Social networks are } \\
\text { predominantly used } \\
\text { to acquire gains }\end{array}$ & $\begin{array}{l}\text { Exist in the first } \\
\text { place to serve a } \\
\text { relationship and to } \\
\text { facilitate trust. Also, } \\
\text { to provide a platform } \\
\text { for exchange of } \\
\text { certain goods and } \\
\text { favors }\end{array}$ & Cause-based & $\begin{array}{l}\text { Serving a } \\
\text { relationship is the } \\
\text { prior purpose }\end{array}$ \\
\hline
\end{tabular}

\section{Discussion}

Despite research on guanxi that can look back on decades of prior research that has already entered the mainstream debates, we still know comparably little about informal social networks in East Asia and Asia at large. While recent studies explore this subject deeper and show that some notions of "trust and achievement in China has the same network correlations associated 
with trust and achievement in the West” (Burt \& Burzynska 2017: 222), Burt and Burzynska (2017) believe that Chinese informal social networks (i.e. guanxi) are still "fundamentally different from networks in the West" (Burt \& Burzynska 2017: 222). Guanxi research shows us that there are structural and characteristic differences between guanxi and social network theory, and this research has shown that by including Korean and Japanese informal networks the deviation is even larger; also, there are remarkable differences between Chinese informal networks on the one hand and Japanese and Korean networks on the other. Hence, a pressing question is why we still know so little about this important theme, including why scholars from East Asia appear to be hesitant to contribute, correct and enrich social network theory based on research on local phenomena.

One explanation could include the argument that we may not have the appropriate methods in place to investigate uniquely local phenomena. For instance, referring to Japanese behavioral patterns, Hamaguchi et al. (1985) doubt that social science has appropriate methods for studying local phenomena "because the social science method that originated in Western Europe has only limited applicability to the study of Japan” (Hamaguchi et al., 1985: 289). In particular, researchers unfamiliar with the research environment run the risk of being blind toward certain phenomena that are difficult to include in a quantitative research design just because they are new and under researched. Here scholars would do well to apply qualitative methods over the dominant and far more popular quantitative approaches (a mixed-methods example combining qualitative and experimental methods in indigenous management research can be found in Horak, 2016). Besides the debate on appropriate methods, a more recent argument focuses on the lack of local initiatives to develop their own theories; instead, more "scholars primarily utilize existing management theories whose substance is based on Western firms [...]. It appears that original theorizing on Chinese business organizations and management is still in a primitive stage, especially in the behavioral areas" (Tsui, Schoonhoven, Meyer, Lau, \& Milkovich, 2004: 137). An explanation for this status is proposed by Mayer (2006) who believes that many Asian scholars just lack the self-confidence to challenge existing theories where they are unsuitable and to push locally-relevant research agendas.

We would like to draw attention to two other arguments of relevance to this discussion. First, another explanation could be that a lack of self-confidence, as Mayer called it, may not be 
the sole reason why Asian scholars engage so little in research on local behavioral phenomena. More likely is that there is a lack of awareness toward the importance and uniqueness of local phenomena. When a researcher is socialized in a certain environment, it easily becomes the "norm" that just isn't very special or interesting to do research on because it is considered "normal." As Ledeneva (1998) explains in relation to her research on interpersonal networks in Russia (blat): "I grew up in such an environment [i.e., an environment in which informal exchange is common], and took most of it for granted. What made me think about blat as something specific was my experience in the West, where I felt things were done differently" (Ledeneva, 1998: 4). Second, a further explanation may be that talking about and revealing information in connection to informal social networks is in some countries a delicate subject and is often even considered a taboo (e.g., in Korea; Horak, 2015). Both facts make an exploration into the structure and characteristics of informal social networks difficult.

Since it is in some way quite remarkable that dominant theories and wisdom on social ties and networks were born in highly individualistic environments, there is an urgent need to understand the social mechanisms in place in countries that are traditionally collectivistic and relationship-oriented. It would be negligent to exclude the latter from any theoretical development claiming universality on the nature of social capital and networks. Future research should first engage in generating more knowledge on the anatomy of local social ties and networks. Second, it should clarify the relationship between local concepts and social capital and networks - and third, enrich, extend or even reject social capital theory depending on the outcome of the analysis (see also Sato, 2013).

Furthermore, the results of this study have important implications for the practice of management. Given that social ties and networks in East Asia predominantly consist of strong ties, are more closed than easy to access, and are to a greater extent driven by a consummatory disposition than strictly instrumental, how can managers gain access to and make use of them? This question is not only of importance for local managers who don't possess influential ties but also for foreign managers (e.g., expatriates) whose task success is often mediated by the receptiveness or openness of the environment. Practical questions of high importance are less about what ties to choose (i.e., strong or weak) and more about how to get access at all, how to 
establish emotional ties and what strategies to pursue in case local access to networks cannot be realized in a satisfactory way.

\section{Conclusion}

By identifying the lack of a contribution of the structure and characteristics of local social ties and networks to core assumptions on social capital and network theory, we analyzed informal social networks in East Asia and performed an intra-regional comparison as well as a comparison to core assumptions of social network theory. We conclude that there are remarkable differences within regional networks as well as when compared with the core assumptions of the conventional social network theory. While instrumental and weak ties do exist, certainly, they cannot be considered the most powerful type of social tie that promises the most benefits to the individual. Social networks in East Asia characteristically consist of strong ties over which resources, benefits and favors are acquired and exchanged. These ties are to a great extent consummatory (and strong) rather than purely instrumental (and weak). Also, the bridging of unconnected networks which results in benefits for the broker and network members is often not intended (e.g., as in Japan) or goes against the ideals in the case of closed and homogenous networks, among which animosities and partial hostility or competition toward each other exist (e.g., as in Korea). Furthermore, gaining access to or acquiring membership is more difficult. There are intra-regional differences. Whereas guanxi is rather open and can be more easily penetrated by outsiders in the long run, yongo in Korea is rather closed and partly predefined. These differences have implications. First, social network research urgently requires further

contributions from local phenomena in order to draw a more realistic picture of the true characteristics and nature of social networks, and to go beyond representing a Western case only. Second, while networks in East Asia tend to consist of strong ties and are rather consummatory and closed, foreign firms (especially Western) need to establish appropriate policies for their managers in order penetrate local networks. 


\section{Endnotes}

1. The terminology for (social) networks in China, Korea, and Japan is often based on the same Chinese characters [Before the introduction of phonographic letters in the $15^{\text {th }}$ century written Korean was based on Chinese characters, which continued to dominate written Korean well into the $19^{\text {th }}$ century. All three Japanese "alphabets" Kanji, hiragana, katakana are based on Chinese characters]. Guanxi, guan-gye, kankei (関 係); renmai, inmaek, jinmyaku (人 脈), yuan, on, en (缘) are the most prominent examples. This implies that mainland Chinese (cultural) traits have been transferred and absorbed in Korean and Japanese societies during various historical episodes. Since their reception, these concepts, however, have been adapted to local circumstances and in the language the respective terms have developed idiosyncratic connotations, significantly deviating from the original Chinese concepts. As such, the authors do not intend to explain differences and commonalities between (social) network designs in China, Korea, and Japan by similarities or differences in their names respectively the underlying Chinese characters.

\section{References}

Aral, S. and Van Alstyne, M. 2011. The Diversity-Bandwidth Trade-off. American Journal of Sociology, 117(1): 90-171.

Adler, N. J., Doktor, R., \& Redding, S. G. 1986. From the Atlantic to the Pacific Century: Cross-Cultural Management Reviewed. Journal of Management, 12(2): 295-318.

Adler, P. S., \& Kwon, S.-W. 2002. Social Capital: Prospects for a New Concept. Academy of Management Review, 27(1): 17-40.

Ambler, T. 1994. Marketing's Third Paradigm: Guanxi. Business Strategy Review, 5(4): 69-80.

Annen, K. 2003. Social capital, inclusive networks, and economic performance. Journal of Economic Behavior \& Organization, 50(4): 449-464.

Aoki, M. 2007. Endogenizing institutions and institutional changes. Journal of Institutional Economics, 3(1): $1-31$.

Barbalet, J., 2015. Guanxi, Tie Strength, and Network Attributes. American Behavioral Scientist, 59(8): 1038-1050.

Baron, R.A. \& Markman, G.D. 2000. Beyond Social Capital: How Social Skills Can Enhance Entrepreneurs' Success. Academy of Management Executive, 14(1): 106-116.

Ben-Porath, Yoram 1980): The F-Connection: Families, Friends, and Firms and the Organization of Exchange. Population and Development Review, 6(1): 1-30.

Bian, Y. 1997. Bringing Strong Ties Back in: Indirect Ties, Network Bridges, and Job Searches in China. American Sociological Review, 62(3): 366-385.

Bian, Y., 1994. Guanxi and the allocation of urban jobs in China. The China Quarterly, 140: 971-999. Blau, P. M., \& Meyer, M. W. 1971. Bureaucracy in modern society. New York: Random House. 
Blunt, P., \& Merrick, L. J. 1997. Exploring the limits of Western leadership theory in East Asia and Africa. Personnel Review, 26(1/2): 6-23.

Bourdieu, P. 1986. The forms of capital. In J. Richardson (Ed.), Handbook of Theory and Research for the Sociology of Education (pp. 241-258). New York: Greenwood.

Buchanan, J. M. 1965. An Economic Theory of Clubs. Economica, 32: 1-14.

Burt, R. S. 1992. Structural holes. New York: Cambridge University Press.

Burt, R. S. 1995. Structural holes: the social structure of competition. Cambridge, Massachusetts: Harvard University Press.

Burt, R. S. 1997. The contingent value of social capital. Administrative Science Quarterly, 42(2): 339365.

Burt, R. S. 2000. The network structure of social capital. Research in Organizational Behavior, 22: 345423.

Burt, R. S. 2001. Structural holes versus network closure as social capital. In N. Lin, K. Cook, \& R. S. Burt (Eds.), Social capital: Theory and research (pp. 31-56). New York: Aldine de Gruyter.

Burt, R. S., \& Burzynska, K. 2017. Chinese entrepreneurs, social networks, and guanxi. Management and Organization Review, 13(2): 221-260.

Chang, K.-C., 2011. A path to understanding guanxi in China's transitional economy: Variation on network behavior. Sociological Theory, 29: 315-339.

Chen, C.C., Chen, X.P., \& Huang, S. 2013. Chinese guanxi: An integrative review and new directions for future research. Management and Organization Review, 9(1): 167-207.

Cheung, M., Wu, W., \& Wong, M., 2013. Supervisor-subordinate kankei, job satisfaction and work outcomes in Japanese firms. International Journal of Cross Cultural Management, 13(3): 265-278.

Chua, V. \& Wellman, B. 2015. Social Networks in East and Southeast Asia I: National Characteristics, Institutions, Network Capital, and Guanxi. American Behavioral Scientist, 59(8): 903-913.

Claridge, T. 2004. Definitions of Social Capital. Retrieved January 1, 2015, from http://www.socialcapitalresearch.com/literature/definition.html

Coleman, J. S. 1988. Social Capital in the Creation of Human Capital. American Journal of Sociology, 94: $95-120$.

Coleman, J. S. 1990. Foundations of social theory. Cambridge, MA: Harvard Business Press.

Dowling, P. J., \& Donnelly, N. 2013. Managing people in global markets-The Asia Pacific perspective. Journal of World Business, 48(2): 171-174.

Durkheim, E. 1933. The division of labor in society. New York: The Free Press.

Fukuyama, F. 2000. Asian Values, Korean Values, and Democratic Consolidation. In L. Diamond \& D. S. Shin (Eds.), Institutional Reform and Democratic Consolidation in Korea (pp. 305-334). Stanford: Hoover Institution Press.

Ghoshal, S. \& Moran, P. 1996. Bad for Practice: A Critique of the Transaction Cost Theory, Academy of Management Review, 21(1): 13-47.

Glaeser, E. L., Laibson, D., \& Sacerdote, B. 2002. An economic approach to social capital. The Economic Journal, 112 (November): 437-458.

Gold, T., Guthrie, D., \& Wank, D., (Eds.) 2002. Social connections in China: Institutions, culture, and the changing nature of guanxi. Cambridge: Cambridge University.

Granovetter, M. 2017. Society and Economy: Framework and Principles. Belknap Press of Harvard University Press: Cambridge, MA.

Granovetter, M. 1995. Getting a Job: A Study of Contacts and Careers. Chicago: Chicago University Press.

Granovetter, M. 1985. Economic Action and Social Structure: The Problem of Embeddedness. American Journal of Sociology, 91(3): 481-510.

Granovetter, M. 1983. The Strength of Weak Ties: A Network Theory Revisited. Sociological Theory, 1: 201-233.

Granovetter, M. S. 1973. The Strength of Weak Ties. American Journal of Sociology, 78(6): 1360-1380. 
Hamaguchi, E., Kumon, S., \& Creighton, M. R. 1985. A contextual model of the Japanese: Toward a methodological innovation in Japan studies. Journal of Japanese Studies, 11(2): 289-321.

Hennart, J.-F. 2015. Leveraging Asian institutions to deepen theory: a transaction cost perspective on relational governance. Asian Business \& Management, 14(4): forthcoming.

Horak, S. 2014. Antecedents and characteristics of informal relation-based networks in Korea: Yongo , Yonjul and Inmaek. Asia Pacific Business Review, 20(1): 78-108.

Horak, S. 2015. The informal dimension of human resource management in Korea: Yongo , recruiting practices and career progression. The International Journal of Human Resource Management, 1-24: forthcoming, doi: http://dx.doi.org/10.1080/09585192.2015.1089062

Horak, S. \& Yang, I. 2016. Affective networks, informal ties, and the limits of expatriate effectiveness. International Business Review, in press, doi: http://dx.doi.org/10.1016/j.ibusrev.2016.01.006

Horak, S. 2016. Join In or Opt Out? A Normative-Ethical Analysis of Affective Ties and Networks in South Korea. Journal of Business Ethics.

Horak, S. 2016. Decision-making behavior, gender differences, and cultural context variables. International Journal of Cross Cultural Management (forthcoming)

Horak, S., \& Taube, M. 2016. Same but different? Similarities and fundamental differences of informal social networks in China (guanxi) and Korea (yongo). Asia Pacific Journal of Management: forthcoming.

House, R. J., Hanges, P. J., Javidan, M., Dorfman, P. W., \& Gupta, V. 2004. Culture, leadership, and organizations: The Globe study of 62 societies. Thousand Oaks: Sage.

Ibarra, H. 1995. Race, Opportunity, And Diversity Of Social Circles In Managerial Networks. Academy of Management Journal, 38(3): 673-703.

Jones, C., Hesterly, W., \& Borgatti, S. 1997. A general theory of network governance: Exchange conditions and social mechanisms. Academy of Management Review, 22(4): 911-945.

Kim, D. O., \& Bae, J. 2004. Employment relations and HRM in South Korea. Hampshire: Ashgate.

Kim, S. 2008. Transcendental collectivism and participatory politics in democratized Korea. Critical Review of International Social and Political Philosophy, 11(1): 57-77.

Kim, Y.-H. 2000. Emergence of the Network Society: Trends, New Challenges, and an Implication for Network Capitalism. Korea Journal, 40(3): 161-184.

Krackhardt, D. 1992. The strength of strong ties: The importance of philos in organizations, in: Nohria, N., Eccles, R.G. (eds.), Networks and Organizations: Structure, Form, and Action (pp. 216-239. Harvard Business School Press: Boston.

Krackhardt, D., \& Stern, R.N. 1988. Informal Networks and Organizational Crises: An Experimental Simulation. Social Psychology Quarterly, 51(2): 123-140.

Ledeneva, A. V. 1998. Russia's economy of favours: blat, networking, and informal exchange. Cambridge: Cambridge University Press.

Ledeneva, A. V. 2003. Informal practices in changing societies: Comparing Chinese guanxi and Russian blat. London: Politics.

Ledeneva, A. V. 2008. Blat and guanxi: Informal practices in Russia and China. Comparative Studies in Society and History, 50(1): 118-144.

Lee, D., Jeong, K.-Y., \& Chae, S. 2011. Measuring Social Capital in East Asia and Other World Regions: Index of Social Capital for 72 Countries. Global Economic Review, 40(4): 385-407.

Lee, J. 2000. Risk, Trust, and Externalities: A Case of Korean Civil Society. Sa-hoi Kwa-hak (Social Science), 39(2): 97-135.

Leung, K. 2008. Chinese culture, modernization and international business. International Business Review, 17(2): 184-187.

Lew, S.-C. 2013. The Korean Economic Development Path - Confucian Tradition, Affective Network. New York: Palgrave Macmillan.

Li, P. P. 2007a. Social tie, social capital, and social behavior: Toward an integrative model of informal exchange. Asia Pacific Journal of Management, 24(2): 227-246. doi:10.1007/s10490-006-9031-2 
Li, P. P. 2007b. Guanxi as the Chinese norm for personalized social capital: toward an integrated duality framework of informal exchange. In H. W. Yeoung (Ed.), Handbook of Research on Asian Business (pp. 62-83). Cheltenham, UK: Edward Elgar.

Li, P. P. 2008. Toward a geocentric framework of trust: An application to organizational trust. Management and Organization Review, 4(3): 413-439.

Li, P. P. 2012. Toward an integrative framework of indigenous research: The geocentric implications of Yin-Yang Balance. Asia Pacific Journal of Management, 29(4): 849-872.

Li, S.J. 2003. Relation-based vs. rule-based governance: an explanation of the East Asian miracle and crisis. Review of International Economics, 11(4): 651-673.

Lin, N. 1995. Local market socialism: local corporation in action in rural China. Theory and Society, 24 (3): 301-354.

Lin, N. 1999. Building a Network Theory of Social Capital. Connections, 22(1): 28-51.

Lovett, S., Simmons, L. C., \& Kali, R. 1999. Guanxi Versus the Market: Ethics and Efficiency. Journal of International Business Studies, 30(2): 231-247. doi:10.1057/palgrave.jibs.8490068

Luo, Y. 2000. Guanxi and Business. (Y. Luo, Ed.)Guanxi and Business. Singapore: World Scientific Publishing Company.

Luo, J. D. 2006. Chinese Renmai - Ego-centric Trust Network. Research in Relational Management, 3: 124.

Luo, J. D. 2011. Guanxi revisited: An exploratory study of familiar ties in a Chinese workplace. Management and Organization Review, 7(2): 329-351.

Mayer, K. 2006. Asian Management Research Needs More Self-confidence. Asia Pacific Journal of Management, 24(4): 527-534.

Nelson, R.E. 1989. The Strength of Strong Ties: Social Networks and Intergroup Conflict in Organizations. Academy of Management Journal, 32(2): 377-401.

Nelson, R. E. 1988. Social Network Analysis as Intervention Tool: Examples From the Field. Group \& Organization Management, 13(1): 39-58.

Park, S. H., \& Luo, Y. 2001. Guanxi and organizational dynamics: organizational networking in Chinese firms. Strategic Management Journal, 22(5): 455-477. doi:10.1002/smj.167

Pool, I. 1980. Comment on Mark Granovetter's 'The Strength of Weak Ties: A Network Theory Revisited.

Portes, A. 1998. Social capital : Its origins and applications in modern sociology. Annual Review of Sociology, 24: 1-24.

Przeworski, A., \& Teune, H. 1970. The logic of comparative social inquiry. New York: John Wiley \& Sons.

Putnam, R. D. 1993. Making Democracy Work. Princeton: Princeton University Press.

Putnam, R. D. 1995. Bowling Alone: America's Declining Social Capital. Journal of Democracy, 6(1): $65-78$.

Pye, L. 1982. Chinese commercial negotiating style. Santa Monica: Rand.

Qi, X. 2013. Guanxi, social capital theory and beyond: toward a globalized social science. The British Journal of Sociology, 64(2): 308-324.

Renshaw, J. R. 2011. Korean Women Managers and Corporate Culture: Challenging Tradition, Choosing Empowerment, Creating Change . Routledge.

Rost, K. 2011. The strength of strong ties in the creation of innovation. Research Policy, 40(4): 588-604.

Sander, T. \& Lowney, K. 2006. Social capital building toolkit (Version 1.2). Saguaro Seminar, Harvard University, John F. Kennedy School of Government: Cambridge, MA. Source: https://sites.hks.harvard.edu/saguaro/pdfs/skbuildingtoolkitversion1.1.pdf

Sandler, T., \& Tschirhart, J. 1997. Club theory: Thirty years later. Public Choice, 93: 335-355.

Sato, Y. 2010. Are Asian sociologies possible? Universalism versus particularism. In M. Burawoy, M. Chang, \& M. F. Hsieh (Eds.), Facing an Unequal World: Challenges for a Global Sociology, Vol. 2 (pp. 192-200). Taipei: Institute of Sociology, Academia Sinica and Council of National 
Associations of International Sociological Association.

Sato, Y. 2013. Social capital. Sociopedia.isa, DOI: 10.1177/205684601374 http://www.sagepub.net/isa/resources/pdf/SocialCapital.pdf

Seibert, S. E., Kraimer, M. L., \& Liden, R. C. 2001. A social capital theory of career success. Academy of Management Journal, 44(2): 219-237.

Sik, S. H. 2005. A brief history of Korea. The spirit of Korean cultural roots. Seoul: Ewha Womens University Press.

Son, J., \& Lin, N. 2008. Social capital and civic action: A network-based approach. Social Science Research, 37(1): 330-349.

Taube, M., \& Schramm, M. 2003. The institutional economics of legal institutions, guanxi, and corruption in the PR China. In J. Kidd and F-J. Richter (Eds.), Fighting corruption in Asia. Causes, effects and remedies: 271-296. London: World Scientific Publishing Co.

Taube, M. 2013. Relational Corruption in the PR China. Institutional Foundations and its (Dys)Functionality for Economic Development and Growth. Comparative Governance and Politics, 7 (1): 89-116.

Tsui, A. \& Farh, L. 1997. Where Guanxi matters - Relational demography and guanxi in the Chinese context. Work and Occupations, 24 (1): 56-79.

Tsui, A. S., Schoonhoven, C. B., Meyer, M. W., Lau, C.-M., \& Milkovich, G. T. 2004. Organization and Management in the Midst of Societal Transformation: The People's Republic of China. Organization Science, 15(2): 133-144.

Watanabe, S. 1987. Job-Searching: A Comparative Study of Male Employment Relations in the United States and Japan. University of California at Los Angeles, Los Angeles, CA.

Weber, M. 1922. Wirtschaft und Gesellschaft. Tübingen: Mohr.

Weber, M. 1951. The religion of China. New York: Free Press.

Williamson, O. 1996. The mechanisms of governance. New York: Oxford University Press.

Williamson, O. 1979. Transaction-cost economics: the governance of contractual relations. Journal of Law and Economics, 22(2): 233-261.

Xiao, Z., \& Tsui, A. S. 2007. When brokers may not work: The cultural contingency of social capital in Chinese high-tech firms. Administrative Science Quarterly, 52(1), 1-31.

Xin, K., \& Pearce, J. 1996. Guanxi: Connections as substitutes for formal institutional support. Academy of Management Journal, 39(6): 1641-1658.

Yang, M. 1994. Gifts, favors, and banquets: The art of social relationships in China. Ithaca: Cornell University Press.

Yazawa, S. 2006. Social Networks in East Asia. Theory, Culture \& Society, 23(2-3): 314-317.

Yee, J. 2000. The Social Networks of Koreans. Korea Journal, 40(1): 325-352.

Yee, J. 2000. Too Modern Too Soon? Dualism in Civil Society, Everyday Life, and Social Relations in Contemporary Korea. Korea Journal, 40(1): 282-284.

Yee, J. \& Nam, E. Y. 2008. The Social Capital of Koreans: Determinants of Personal Ties and Its Effects (in Korean). Korean Journal of Sociology, 42(7): 178-214.

Zhan, J. V. 2012. Filling the gap of formal institutions: The effects of guanxi network on corruption in reform-era China. Crime Law and Social Change, 58(2): 93-109. 


\section{DuEPublico}

Duisburg-Essen Publications online
DEUSISBN R G

offen im Denken

This text is made available via DuEPublico, the institutional repository of the University of Duisburg-Essen. This version may eventually differ from another version distributed by a commercial publisher.

DOI: $\quad 10.1007 / \mathrm{s} 10490-018-9602-\mathrm{z}$

URN: urn:nbn:de:hbz:464-20200205-175745-7

This is a post-peer-review, pre-copyedit version of an article published in Asia Pacific Journal of Management, 36, 349-372 (2019).

All rights reserved. 